\title{
Rationalising religion: The role of religion and conscience in Australian politics
}

\author{
JONATHAN TJANDRA
}

\section{Abstract}

This article investigates the complex problem of the role of religion in Australian politics. As a liberal democracy, Australia is a state in which the establishment of a state religion is prohibited and the free expression of religion is upheld. Religionists, like all citizens, are free to express their personal opinions but any religious motivations should be translated into secular reasons if their opinions are to be given any weight in public policy. I trace the development of the separation of church and state, and evaluate its contemporary usefulness for understanding religion and politics in Australia. Particular regard is paid to the idea that religious authorities command the beliefs of their adherents. A case study investigating the influence of religion in the debate surrounding communism in the 1950s is analysed. In a representative democracy like Australia, it is expected that politicians represent their electorate rather than being accountable to religious authority, so this article investigates its origins in theology and its effectiveness. I propose that it would be useful to reframe our thinking about how religion informs an individual's convictions, by viewing religion as one of many influences that shape one's conscience. Finally, I combine and evaluate existing threads in the literature to weave a starting point of a unified 'systems theory of conscience' to the extent its key determinants affect public policy.

\section{Introduction}

The role of religion in public policy is a divisive issue. The role of religion has been increasingly questioned in government, even as it has been for centuries. As a liberal democracy, Australia is a secular state, but religion is often seen as a key determinant in policymaking. Philosophers such as John Rawls have argued the deep divisions of religious belief in pluralistic, democratic societies make it impossible for agreements 
to be made for the good of the entire society. ${ }^{1}$ I will argue it is not fruitful to think of religion in politics in this way and that we need to reform the way we think about religious convictions in public policy.

Generally, there are three main objections to religious motivations in government, which emerged over time as the doctrine of separation of the church and state. ${ }^{2}$ First, the public takes issue with the idea that elected politicians 'blindly follow' the demands of religious authorities instead of voters. ${ }^{3}$ Second, religious beliefs are by nature difficult to argue against in a legislature, especially debates between different religions. ${ }^{4}$ Third, the issue is raised whether it is possible for religion to be practised by all citizens in the public domain while showing respect to other religious beliefs (and none). ${ }^{5}$ Current events such as the rise of the Islamic State and the increasing popularity of Pope Francis represent a convergence of the church and state; as such, some scholars characterise the contemporary era as 'post-secularist'. ${ }^{6}$ We cannot ignore that people are motivated by religious beliefs, so I propose complete separation is not the answer.

\section{A brief background}

Australia has always been a secular state, and fiercely so. Australians are often suspicious of religious authorities, for example, when Paul Keating famously called Frank Brennan a 'meddling priest' during the debates surrounding the Wik judgment in $1998 .^{7}$ A politician cannot be taken seriously unless they can argue convincingly for their policy; it is not enough to rely on religious authority. Thus, when Archbishops Peter Jensen of the Anglican Church and George Pell of the Catholic Church wanted to criticise the Howard Government's industrial relations reform in 2005 , they had to do so on secular terms and representing their own personal opinions. ${ }^{8}$

\footnotetext{
John Rawls, 'The Idea of an Overlapping Consensus', Oxford Journal of Legal Studies, vol. 7, no. 1, 1987, p. 1. Frank Brennan, Acting on Conscience, Queensland University Press, 2007, p. 21.

Ibid., p. 24.

Ibid.

Ibid., p. 22.

Erin Wilson, After Secularism: Rethinking the Role of Religion in Global Politics, Basingstoke, UK, Palgrave

$7 \quad$ Paul Kelly, The March of Patriots, Melbourne University Press, 2009, p. 390. The Wik judgment of the High Court of Australia found that pastoral leases did not necessarily extinguish native title, and is part of a series of High Court cases in which native title was considered. These were highly controversial cases in Australian society
} Macmillan, 2012. at the time.

8 Brennan, p. 16. 
This translation into secular reasoning is known as the principle of secular rationale:

One should not advocate any law or public policy that restricts human conduct unless one has, and is willing to offer, adequate secular reason for this advocacy. ${ }^{9}$

The principle does not proscribe religious motivations, but if one chooses not to translate them into secular reasons, these arguments are not countenanced. However, it is unclear whether this principle is actually desirable. Any secularisation is manipulative at best or deceptive at worst, as one would be misrepresenting one's actual beliefs. ${ }^{10}$

The effect can be seen in the same-sex marriage debate. Religious organisations such as the Australian Christian Lobby make secular arguments by articulating social and cultural reasons for the traditional definition of marriage, or may include an appeal to the rights of children. ${ }^{11}$ The current discussion can be summarised as whether state marriage should be a reflection of religious ones or if there is a separation between the two concepts. Jesuit priest and academic Frank Brennan laments:

How could I explain myself to [supporters of same-sex marriage]? Could I do this without referring to my beliefs? Being a Catholic priest, I am a member and representative of a church which not only recognises that marriage as the indissoluble union between a man and a woman, but which also defines marriage to be a sacrament. ${ }^{12}$

Here, he makes the argument that it would be difficult, if not misleading, to portray his sincerely held motivations as purely secular, as his reasoning is in fact religious.

The forerunner to the idea of separation of politics and religion is found in Martin Luther's 'two kingdoms' doctrine, outlining the difference between the secular or civil life, and the sacred or ecclesiastical life. ${ }^{13}$ This teaching was grounded in the book of Romans, where it too made the distinction between the earthly things and spiritual things. ${ }^{14}$ As part of the wider Protestant Reformation, Luther was critical of the Roman Catholic Church and how it was corrupted by temporal politicking of the time. Hence, he proposed the need for a division, to prevent the Church from being corrupted.

This idea was taken up by the English Parliament and became one of the cornerstones of the Enlightenment era, especially as Protestant England tried to free itself from the influence of the Catholic Church. Opinions ranged from former British Prime

9 Robert Audi, 'The Separation of Church and State and the Obligations of Citizenship', Philosophy \& Public Affairs, vol. 18, no. 3, 1989, p. 279.

10 Ibid., pp. 281-283.

11 Australian Christian Lobby, Marriage, www.acl.org.au/marriage, 2016, (accessed 24 September 2016).

12 Brennan, p. 185.

13 Brent W. Sockness, 'Luther's Two Kingdoms Revisited', The Journal of Religious Ethics, vol. 20, no. 1, 1992, p. 93.

14 Romans 8:1-11. See also Romans 13 and 1 Peter 3:9. English Standard Version. 
Minister Lord Melbourne's statement, 'Things have come to a pretty pass when religion is allowed to invade public life', to Edmund Burke's argument, 'We know, and, what is better, we feel inwardly, that religion is the basis for civil society'. ${ }^{15}$ This was the foundation of the modern concept of the separation of church and state, although it has become more prevalent since then.

\section{Problems of definition}

Note that the background provided in the previous section drew exclusively on Christian and Western philosophers. This is because the doctrine of separation is an almost exclusively Western development, with roots in the Abrahamic traditions and spread throughout the world by colonisation. ${ }^{16}$ Non-Western cultures had no such separation, and religion was seen as inseparable from everyday life and culture. ${ }^{17}$ Thus, one problem is the vagueness of what constitutes a religion. This leads to a narrowing of 'religion' in public discussion, so minority religions and cultures are marginalised.

An example of marginalisation can be found in the contemporary same-sex marriage debate. In 2015, 30 Indigenous Australian elders launched the Uluru Bark Petition, which argued for the traditional definition of marriage according to their ancient traditions and culture. ${ }^{18}$ The media's focus on Christian opposition to same-sex marriage comes at a cost of the marginalisation of these minority cultures.

There is not so much debate over what religion actually is, but over what anthropological phenomena it represents. ${ }^{19}$ Thus, a common definition might be 'a set of beliefs involving God', but this definition fails an ostensive test-it does not describe what we want to describe as it excludes parts of Buddhism. If we weaken the definition to simply 'belief in spirits or supernatural entities', this excludes Confucianism, and so on. What remains is just 'a set of beliefs' part of some 'cultural institution'; necessary but not sufficient for religion. ${ }^{20}$ In these traditions

15 Edmund Burke, Reflections on the Revolution in France, Pall Mall, London, James Dodsley, 1790, p. 75. For more works of Enlightenment scholars on this topic see John Milton, A Treatise of Civil Power in Ecclesiastical Causes, London, J. Johnson, 1790, original publication 1659; and Lord Peter King, 'On the Difference Between Civil and Ecclesiastical Power', The Life and Letters of John Locke, 1858.

16 See Stephen M. Feldman, Please Don't Wish Me a Merry Christmas: A Critical History of the Separation of Church and State, New York University Press, 1997. Also J. Judd Owen, Religion and the Demise of Liberal Rationalism: The Foundational Crisis of the Separation of Church and State, University of Chicago Press, 2001.

17 For an excellent summary, see Kwame Anthony Appiah, Is religion Good or Bad? (This is a Trick Question), in TEDSalon NY2014, edited, 2014, www.ted.com/talks/kwame_anthony_appiah_is_religion_good_or_bad_ this_is_a_trick_question. Also see Durkheim's work on the sociology of religion.

18 Uluru Bark Petition, About: Uluru Bark Petition, ulurubarkpetition.com, 2015, (accessed 24 September 2016).

19 Melford E. Spiro, 'Religion: Problems of Definition and Explanation', in Michael Banton (ed.), Anthropological Approaches to the Study of Religion, London, Routledge, 1966, p. 87.

20 Ibid., p. 96. 
of anthropology, the broad definition includes things not normally thought of as religion, such as tribal lore and customs. This definitional ambiguity is the foundation of the idea that religion is just as rational as cultural beliefs and traditions.

\section{Case study: Communism in Australia}

Bringing it back to Australia, this next section looks at how religious beliefs played a part in the 1951 debates around the banning of the Australian Communist Party, and draws a connection between religious beliefs and political ideology. The fact that state atheism is a cornerstone of Marxism is well-documented. Marx himself wrote of the competing roles of religion and his own ideology in determining 'real happiness' ${ }^{21}$ Furthermore, Lenin argued religious motivations were nothing more than the 'organs of bourgeois reaction' and inseparable from capitalist ideology. ${ }^{22}$ The thrust of the argument is that religion, like opium, fulfils an illusory desire and hinders human development. ${ }^{23}$

In the mid-twentieth century, Australian Catholics were virulently anti-communist due to communism's focus on humanism, materialism and determinism, ideals hostile to Catholic teachings. ${ }^{24}$ Consequently, the Church often published anticommunist literature countering Marxist teachings. Combined with the tensions of the Cold War, this contributed to the Catholic's 'ideological crusade' against communism in Australia. ${ }^{25}$

In 1950, the Menzies Government attempted to ban the Communist Party of Australia by passing the Communist Party Dissolution Bill. It was challenged in the High Court and found to be unconstitutional, so a referendum was held in 1951 to overcome the ruling. Ultimately, the referendum failed.

Fears of the influence of the communists in the Australian Labor Party (ALP) persisted. ${ }^{26}$ It was the key factor in the Labor split of 1955, after which expelled members ran for re-election as the Australian Labor Party (Anti-Communist), and that in turn led to the establishment of the Democratic Labor Party (DLP). ${ }^{27}$ B.A. Santamaria, the founder of the DLP, was both a conservative Catholic and a staunch anti-communist, and, as a result, the foundation of a new party promoting Catholic values was thought to have the effect of combating communism in the new party. ${ }^{28}$

21 Karl Marx, Critique of Hegel's Philosophy of Right, Oxford University Press, 1970, original publication 1844, p. 1.

22 Vladimir Ilyich Lenin, 'The Attitude of the Workers' Party to Religion', in Andrew Rothstein and Bernard

Issacs. (ed.), Lenin Collected Works, Moscow, Progress Publishers, 1973, original publication 1909, vol. 15, p. 1.

23 Marx, p. 8.

24 Bruce Duncan, Crusade or Conspiracy? Catholics and the Anti-Communist Struggle in Australia, University of New South Wales Press, 2001, p. 11.

25 Ibid., pp. 19-20.

26 Robert Murray, The Split: Australian Labor in the Fifties, F. W. Cheshire, 1970, pp. 12-13.

27 Ibid., pp. 249-256.

28 Duncan, pp. 14-20. 
The common thread in these debates is that Catholicism and communism provide mutually exclusive sources for one's conscience and in public policy. It should be noted that both systems appealed mainly to the working class. On one hand, religion was seen as inseparable from capitalist suppression of the working class. On the other hand, communism was seen as promoting atheistic materialism and class conflict as the only true way of satisfying one's desires. It could therefore be argued that religion and political ideologies are just as rational as each other.

\section{Religious authority}

The anti-communist beliefs of Australian Catholics were encouraged by the teachings of the Holy See, most directly in the papal encyclical Divini Redemptoris (proclaimed in 1937 by Pope Pius XI). This begs the wider question: to what extent do religious authorities command the beliefs of their adherents, particularly politicians?

The Roman Catholic Church is the strictest when it comes to the infallibility of religious authorities; other Christian denominations and other religions do not have similar doctrines. ${ }^{29}$ This is espoused in the teaching of the First Vatican Council of 1870 , which held that the Pope could infallibly define a 'doctrine of faith or morals' ${ }^{30}$ The conflict between religious authority, conscience and the state was described by former British Prime Minister Gladstone: 'no one now can become [Catholic] without renouncing his moral and mental freedom, and placing his civil loyalty and duty at the mercy of another'. ${ }^{31}$

Although the Pope is infallible on moral and faith issues, one can in good faith and after much contemplation go against these doctrinal truths if it is against one's conscience. There is much debate amongst Catholic theologians about the scope of this teaching. ${ }^{32}$ Drawing on Augustine of Hippo and Thomas Aquinas, the Second Vatican Council of 1965 teaches: 'in all his activity, a man is bound to follow his conscience faithfully, and one should not be forced to go against or be prevented from going with one's conscience'. ${ }^{33}$

As a corollary, the clergy are free to express their personal opinions and, drawing on their expertise, they can authoritatively proclaim interpretations of holy texts. However, due to the nature of people's consciences, they can hardly claim to speak for their entire religion when it comes to matters of public policy. It is equally plausible

29 W. E. Gladstone, The Vatican Decrees in their Bearing on Civil Allegiance, London, John Murray, 1874, p. 10.

30 Vatican I Council, Pastor Aeternus: First Dogmatic Constitution on the Church of Christ. Published in the Fourth Session of the Holy Ecumenical Council of the Vatican, 1870.

31 Gladstone, p. 12.

32 Brennan, pp. 28-49.

33 Vatican II Council, Dignitatis Humanae: Declaration on Religious Freedom Proclaimed by Pope Paul IV, 7 December 1965. 
that one may agree with these interpretations, but disagree about the proper role of legislation and the state in enforcing those beliefs. Consequently, it does not make sense to say elected politicians follow blindly the wishes of religious authorities.

\section{On conscience}

Instead of seeing religious convictions as antithetical to liberal democracies, my proposal is to recategorise it as just one of many influences contributing to one's conscience. In previous sections, I have argued that religious arguments are no different from cultural or ideological arguments, and now I extend the argument further to other sources of belief. Figure 1 is a diagram that depicts several (non-exhaustive) factors that influence one's conscience.

Factors such as religion, culture, ideology, family and friends, socioeconomic background and education influence each other and contribute to one's conscience. For a politician, additional constraints may be added due to the influence of their political party, incentives or their electorate-it is usually the case that party discipline plays a much more important role than any other influence. This translates into policy outcomes, generating feedback from the public and the media, potentially leading to changes in one's beliefs and thus changes in policy.

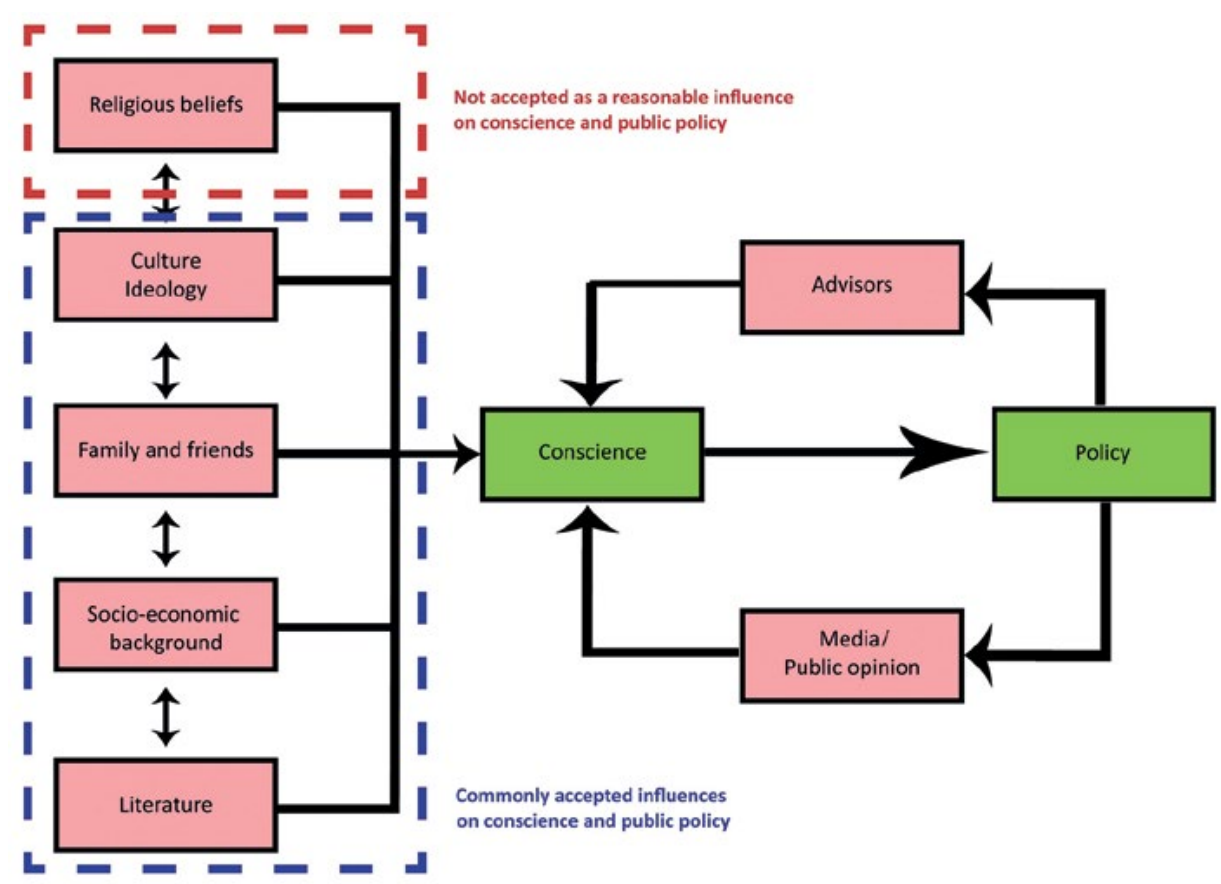

Figure 1: Diagram illustrating factors influencing one's conscience. Source: Author. 
I posit that religious motivations are just as valid as other motivations, as they all influence our consciences, and are all influenced by our consciences. It does not make sense to arbitrarily exclude one source and not the others. In Hollenbach's terms, 'Persons or groups should not face political disability or disenfranchisement simply because their political views are rooted in religious traditions and beliefs' ${ }^{34}$ Of course, one could just exclude all of the other motivations, but then we are left with no other way of determining policy.

Whilst this may seem radical in an Australian or Western democratic context, it is well documented in other countries, especially communist ones. Continuing the theme of Marxism and religion, Chinese President Xi Jinping issued a directive in 2016 that '[Communist Party] members should not seek alternative values and beliefs in religion', illustrating his fears that religion will overtake Marxism as the dominant source of conscience in China. ${ }^{35}$ Indonesia in 1965 took the opposite approach after a failed communist coup, and made religion mandatory in hopes that religious beliefs would counteract Marxist political ideology. ${ }^{36}$ Whilst I disagree with Marx about the purposes of religion, I agree that religion is of the same type as political ideology to the extent it informs one's conscience.

The effect of the change in mindset would be that religious convictions are treated in the same way as any other conviction and are accepted as reasonable motivation for policy. This also means religious beliefs should be debated to the same standard as other beliefs: religious leaders should not just proselytise their views or attempt to influence political debate like any other self-interested lobbyist. Rather, they should engage critically with their beliefs rather than seek to use state power to legitimise their beliefs, especially given their position of trust in society. ${ }^{37}$ Some policies may be informed by religious doctrine, but they should be compared with other sources of policy before implementation. ${ }^{38}$

Thus, when a religious authority argues against, say, euthanasia, a religious politician might take the same view, but not simply on some Archbishop's proclamation. Rather, it would be because those arguments fit in with other values and beliefs held by their constituents coming from sources other than religion. In a liberal democracy, individuals and communities are free to hold these views privately,

34 David Hollenbach, 'Contexts of the Political Role of Religion: Civil Society and Culture', San Diego Law Review, vol. 30, no. 4, 1993, p. 897.

35 Rowan Callick, 'Religious Groups Wary of Xi's Call for "Unyielding Marxist Atheists", The Australian, 27 April 2016, section 'The World'.

36 Jaques Bertrand, Nationalism and Ethnic Conflict in Indonesia, Cambridge University Press, 2004, p. 74.

37 For an explanation of what a 'good' religious argument is and how it could be used in public debate, see Robert Audi, 'The Place of Religious Argument in a Free and Democratic Society', San Diego Law Review, vol. 30, no. 4, 1993.

38 Hollenbach, p. 898. 
and the state should not prevent them from doing so. Similarly, churches should recognise the importance of one's personal conscience in determining one's actions and not prevent adherents from exercising their conscience.

Problems about how some religious beliefs are incompatible with others would be dealt with in the same way as differences in political ideology are solved in parliament, that is, through parliamentary debate and procedural voting. Consider two politicians, a socialist and a free-marketeer. They can plausibly work together in parliament even though their beliefs are incompatible. Informed by intellectual authorities such as Marx and Hayek, they each assert their own policies on their consciences (and restricted by party lines), yet are able to achieve policy outcomes in the form of legislation. I argue there should be no difference when it comes to religious beliefs.

\section{Conclusion}

This would result in a society where religion, public policy, culture and other sources of conviction are integrated, though power remains in the hands of elected representatives rather than unelected lobbyists. It seems a complete separation is, in part, a contributing factor of why religious debates are so divisive in the first place as it restricts religious-based discussions to religious authorities instead of allowing a wider participation. Religion can often raise important ethical challenges to the existing political status quo and, in dialogue with the wider community, create a cultural consensus on moral issues as diverse as slavery and abortion.

This is similar to how ideologies are just as divisive as religions. However, these beliefs are regularly debated in parliament or the media, and yet can still translate into real policy outcomes. Through these reasoned discussions, it is possible to create a new society in which all religions and motivations are at least respected.

The practical effect of the exclusion of religious beliefs in public policy is essentially one of disenfranchisement of those who hold religious beliefs. I argue that this does not seem right, especially if religious motivations are of the same type as motivations influenced by ideology, culture or others, to the extent these sources of motivation influence one's conscience. Just like the other motivations, religion is not only a set of beliefs or an anthropological phenomenon, but can make meaningful contributions to public policy.

In a multicultural, democratic society such as Australia, we can no longer ignore the competing influences of different cultures and religions on Australian society. In this essay, I have drawn on mainly Christian traditions to argue for the idea of including religion in public debate because it is the dominant source of religious conscience in Australia, but this does not have to be the case in the future. 
Indeed, it would be detrimental if members of different traditions did not engage critically with each other. A truly free society is one in which all people are able to take part in the conversations that shape public policy, guided by principles of respect, the pursuit of truth and concern for the overall good of the society. My argument is that religious convictions do have a place in this society.

\section{Bibliography}

Appiah, Kwame Anthony. (2014). Is religion Good or Bad? (This is a Trick Question) [Video file]. Retrieved from www.ted.com/talks/kwame_anthony_appiah_is_ religion_good_or_bad_this_is_a_trick_question.

Audi, Robert. (1993). 'The Place of Religious Argument in a Free and Democratic Society'. San Diego Law Review, 30(4), 677-702.

Audi, Robert. (1989). 'The Separation of Church and State and the Obligations of Citizenship'. Philosophy \& Public Affairs, 18(3), 259-296.

Australian Christian Lobby. (2016). Marriage. Retrieved from www.acl.org.au/ marriage (accessed 24 September 2016).

Bertrand, Jaques. (2004). Nationalism and Ethnic Conflict in Indonesia, Cambridge: Cambridge University Press.

Brennan, Frank. (2007). Acting on Conscience. St Lucia: Queensland University Press.

Burke, Edmund (1790). Reflections on the Revolution in France. Pall Mall, London: James Dodsley.

Callick, Rowan. (2016, 27 April). 'Religious Groups Wary of Xi's Call for "Unyielding Marxist Atheists", The Australian, section 'The World'.

Crossway Bibles. (2007). ESV Study Bible: English Standard Version. Wheaton, Illinois: Crossway Bibles.

Duncan, Bruce. (2001). Crusade or Conspiracy? Catholics and the Anti-Communist Struggle in Australia. Sydney: University of New South Wales Press.

Feldman, Stephen M. (1997). Please Don't Wish me a Merry Christmas: A Critical History of the Separation of Church and State. New York: New York University Press.

Gladstone, W. E. (1874). The Vatican Decrees in their Bearing on Civil Allegiance. London: John Murray. 
Hollenbach, David. (1993). 'Contexts of the Political Role of Religion: Civil Society and Culture'. San Diego Law Review, 30(4), 877-901.

Kelly, Paul. (2009). The March of Patriots. Carlton: Melbourne University Press.

King, Lord Peter. (1858). 'On the Difference Between Civil and Ecclesiastical Power', The Life and Letters of John Locke, 300-306.

Lenin, Vladimir Ilyich. (1973). 'The Attitude of the Workers' Party to Religion'. In Andrew Rothstein and Bernard Issacs (eds), Lenin Collected Works (Vol. 15). Moscow: Progress Publishers (original work published 1909), 402-413.

Marx, Karl. (1970). Critique of Hegel's Philosophy of Right. Oxford: Oxford University Press (original work published 1844).

Milton, John. (1790). A Treatise of Civil Power in Ecclesiastical Causes, edited, London, J. Johnson, (original work published 1659).

Murray, Robert. (1970). The Split: Australian Labor in the Fifties. Melbourne: F. W. Cheshire.

Owen, J. Judd. (2001). Religion and the Demise of Liberal Rationalism: The Foundational Crisis of the Separation of Church and State. Chicago: University of Chicago Press.

Rawls, John. (1987). 'The Idea of an Overlapping Consensus'. Oxford Journal of Legal Studies, 7(1), 11-25. doi.org/10.1093/ojls/7.1.1

Sockness, Brent W. (1992). 'Luther's Two Kingdoms Revisited'. The Journal of Religious Ethics, 20(1), 93-110.

Spiro, Melford E. (1966). 'Religion: Problems of Definition and Explanation', in Michael Banton (ed.), Anthropological Approaches to the Study of Religion, 85126. London: Routledge.

Uluru Bark Petition. (2015). About: Uluru Bark Petition. Retrieved from ulurubarkpetition.com (accessed 24 September 2016).

Vatican I Council. (1870). Pastor Aeternus: First Dogmatic Constitution on the Church of Christ. Published in the Fourth Session of the Holy Ecumenical Council Of the Vatican.

Vatican II Council. (1965, 7 December). Dignitatis Humanae: Declaration on Religious Freedom Proclaimed by Pope Paul IV.

Wilson, Erin. (2012). After Secularism: Rethinking the Role of Religion in Global Politics, Basingstoke, UK: Palgrave Macmillan. 
This text is taken from The ANU Undergraduate Research Journal, Volume Eight, 2016, edited by Daniel McKay, published 2017 by ANU eView, The Australian National University, Canberra, Australia.

dx.doi.org/10.22459/AURJ.08.2016.08 